\title{
EVALUATION OF SOME BIOINECTICIDES AGAINST BEMESIA TABACI (GENN.) And EFFECT ON YIELD COMPONENT OF CUCUMBER
}

\author{
SAYED, M. M. EL - GARHY \\ Plant Protection Research Institute, ARC, Dokki, Giza, Egypt
}

(Manuscript received 7 Aujust 2012)

\begin{abstract}
Bemisia tabaci (Genn.) is considered the main factor of yellow leaf curl virus for cucumbers and other crops such as tomato, pepper, aubergine, okra, soybean, cotton and ornamental plants. Field trials were conducted in Fayoum Governorate, district of Fayoum on four cucumber varieties in four transplantations dates; $1 / 3,1 / 4,1 / 9$ and $1 / 10 / 2011$ to study the efficiency of the bioinsecticides, Mycotal (Verticillium lecanii), Biosect (Beauveria bassiana) and their mixture as well as Capel 2 E.C against the second instar nymphs of the whitefly B. tabaci. Tested cucumber varieties were Medina, Amera, Dama and Maram.

In that concern, Dama variety proved to be less sensitive and the mean of reduction was $(79.8 \%)$ and Amera was more sensitive showing reduction rate of (94.7\%) in $1 / 3 / 2011$.
\end{abstract}

\section{INTRODUCTION}

Cucumber (Cucumis sativus L.) is one of the most important vegetable crops cultivated in or outdoors plantations. Fayoum Governorate is one of the most important Governorates in planting vegetables either for export or consumption. $B$. tabaci (Genn.) is one of the most important pests attacking tomato plants. B. tabaci (Gennadius) (Hemiptera: Aleyrodidae), B and Q whiteflies, have been invading many parts of the world (Tsueda and Tsuchida 2011). Recently Bemisia tabaci is the main factor of tomato yellow leaf curl virus (TYLCV) transmit that severely invaded tomato, cucumber, eggplants and pepper. (Fargalla et. al., 2011). (Rao et. al., 2008) reported that cucurbit yellow stunting disorder virus (CYSDV) and the whitefly-transmitted closterovirus, affects extensively cucurbit crops in many warm and temperate areas of production worldwide.

In Egypt, B. tabaci can complete its development on 118 species of plants in 79 genera belong to 28 families, (Abd-Rabou, and Simmons, 2010). B. tabaci represents a complex of cryptic species that causes losses of many valuable crops. Even though there are differences in their ability to colonize hosts, transmit phytovirus and develop resistance to insecticides, (Fontes et. al., 2012). Although extensive research about biological control of whitefly by parasitoids and predators has been conducted, entomopathogenic fungi can be considered as potential biological control agents, (Scorsetti et. al., 2008). 
The aim of this study was to control $B$. tabaci with entomopathogens as alternative to pesticides.

\section{MATERIALS AND METHODS}

The experiment were conducted in different sowing dates 1 / 3, 1 / 4/, 1 / 9 and 1 / 10 / 2011. Four varieties of cucumber ( Madena, Amera, Dama and Maram) were sown in foam trays under plastic tunnels in Seedling Section Unit, Department of Agriculture, Fayoum Governorate. The seedlings were transplanted at 30 days age. The area was divided into four equal replicates of $(3 \mathrm{~m} \times 80 \mathrm{~cm})$ per replicate for each treatment. Treated and untreated plots were arranged in a complete randomized block design, receiving routine agriculture practices. Tested biocides were Mycotal (Verticillium lecanii), Biosect (Beauveria bassiana), their mixture and Caple 2. The biocides were applied after 30 days from transplanting date. A motor of high pressure knapsack sprayer was used for applying the biocides, as a foliar treatment diluted with water as recommended, Mycotal $1 \mathrm{~g} / \mathrm{I}$, Biosect, $2 \mathrm{~g} / \mathrm{I}$, their mixture and Caple 2, 2.5 $\mathrm{ml} /$ liter water. To estimate the percentage of infestation with B. tabaci 15 leaves / replicate were collected at random. Sampling was done before spraying and after 3, 5, 7, 10 and 15 days early morning. Population density of the second instar nymphs was calculated by transplanting the plant leaves in paper bags to the laboratory for inspection with the aid of stereomicroscope. To evaluate of tested compounds against B. tabaci, population density currently estimated, calculated and corrected according to the formula of Henderson and Telton (1955). Data were analyzed by 1- way analysis of variance (ANOVA), analysis of variance and LSD values were obtained at 0.05 level, using SAS program (SAS Institute, 1988). Means were separated by Duncan's multiple range tests. Reduction and the mean reduction percentages were based on the overall mean population within 15 days.

Harvesting of fruits starting after 45 days from the transplanting date and ended after 90 days in all experiments. Before harvesting, ten plants from each replicate were randomly collected for average number of fruits / plant, fruit length $(\mathrm{cm})$, fruit diameter $(\mathrm{cm})$ and weight of fruit $(\mathrm{gm})$.

\section{RESULTS AND DISCUSSION}

Data in tables $1-4$ show that cucumber was highly infested by $B$. tabaci. The infestation ranged between (45.5 to 90.0 nymphts / 15 leaves in different dates of cultivations. Lowest infestation occurred in variety Madena, ranged between 32.4 to 
64.2 / 15 plant leaves in different cultivation dates, while Amera and Dama varieties had moderate infestations in this respect.

Concerning the cultivation date, lowest infestation occurred in $1 / 3 /$ 2011transplantation, while the highest one was reported in $1 / 10 / 2011$, as presented in tables (1, 2, 3 and 4).

Statistical analysis of the obtained data show significant differences in the white fly infestations of the four testing varieties. The effect of different bioinsecticides on the population of the whitefly is presented in tables 1-4. All bioinsecticides significantly reduced the population density of the pest as compared with the untreated control. The results indicated a high and rapid reduction in insect density 3-15 days after spraying and the highest percent of reduction was in the mixture of (Micotal and Biosect), Biosect and Micotal showing (85.0, 90.2, 90.290 .6 \& 89.1, 90.2, 90.2, \& 90.6 and 89.9, 92.1 92.0, 92.1 and 91.5, 91.7, 91.0, 90.4\% reduction on Madena, Amera Dama, and Maram cultivars in four transplantation dates, respectively. A satisfactory reduction in B. tabaci density was recorded after spraying Caple 2 which achieved lower effect at the aforementioned times. The mean percents reduction were $72.3,75.8,77.8 \& 77.2 \& 83.8,85.4,87.1,87.6 \& 86.1,86.7$, $88.5,88.1$ and85.9, 86.8, $87.9 \& 88.4 \%$ on the four cultivars in the four transplantation dates, respectively. The tested compounds could be arranged according to the general reduction in population density of the pest after 15 days in the following descending order: the mixture, Micotal, Biosect and Caple2.

Statistical analysis of the obtained data indicated a significant difference between the mixture and the other tested bio-insecticides after 3 days, while there was no significant difference between Mycotal and Biosect after 3days of application. However, there were no significant differences among the effect of all bio- insecticides used after 3 and 15 days of application. On the other hand, there were significant differences between the effect of each of the mixture, Micotal, Biosect used after 3 and 15 days of application and Caple 2, (Table 1).

As shown in tables (1-4), it is clear that the mixture of Micotal and biosect was the superior compound after 3 days of application, since it gave 94.7 reduction in B. tabaci population infesting cucumber that transplanted in $1 / 3 / 2011$. Biosect came next in this respect followed by Micotal and Caple 2 which showed inferior efficacy among the tested bio-insecticides. 
These results are in agreement with those obtained by Dattatray and Uttamrao (2009) who reported that significant differences among various treatments were observed after 3, 7 and 10 at days after spraying. All the treatments were superior over the control in reducing whitefly population.

Olleka et. al., (2009) found that percent survival of B. bassiana were applied on second-instar nymphs of $B$. tabaci, ten days after inoculation with $1 \times 10^{8}$ conidia / $\mathrm{ml}$, was 4.2+or-0.7, 9.6+or-0.4, 13.4+or-0.8, and 24.3+or-0.9\% on cucumber, eggplant, tomato and cabbage, respectively. Average survival times of nymphs were also significantly influenced by host plant species. Survival times were $4.8+$ or- 0.15 , $6.0+$ or- $0.11,5.7+$ or- 0.13 , and $6.2+$ or- 0.08 days for nymphs reared on cucumber, eggplant, tomato, and cabbage, respectively.

Tandon et. al., (2007) reported that several commercial formulations based on entomopathogenic fungi were developed for the control of sucking pests in different countries. Mycotrol and Botanigard based on B. bassiana, Mycotal based on V. lecanii and PFR-97 and Pae-Sin based on Paecilomyces fumosoroseus were developed for the control of whiteflies, aphids and thrips in USA, Europe and Brazil. In India. Oil formulations have been found to be more effective against target pests even under low RH and also possess a good shelf life.

Considering the dates of transplantation, it is obvious that transplanting cucumber in 1 / 3 / 2011 showed the lowest rate of infestation by the pest ranged between 32.4 and 45.5 adults / 15 plant leaves, (Table 1), while cucumber transplanted in $1 / 10$ / 2011 showed the highest of infestation ranged between (64.2 and 77.5) adults / 15 leaves, (Table 4).

Regarding transplanted varieties, it is evident that Dama variety was more tolerant to the infestation of cucumber than the other varieties. However, the variety Amera was the most susceptible to whitefly infestation in1 / 3 / 2011 transplantation, while Madena variety was more tolerant 1 / 4 / 2011 and 1 / 9 / 2011. It also clear to indicate that, Maram appeared more tolerant and Amera the most susceptible in 1 / $10 / 2011$.

The effect of the bio-insecticide on the fruits / plant is shown in (Table 5). The results indicated that number of fruits was not affected by the date of transplantation. However, there were significant differences among varieties, Madena showed highest mean number of fruits / plant, ranged between 15.023 .5 , followed by Amera, 15.3 - 23.1, Dama, 15.0 - 23, and Maram 15.0 - 23.3.

The treatment with the mixture of Micotal and Biosect had the superior effect on the mean number of fruits, it showed a range of $21.5-23.5,21.0-23.1,21.0-$ 23.0 and 21.0 - 23.3fruits / plant in different varieties, Madena, Amera, Dama and 
Maram, respectively, followed by biosect 23.0 - 21.0, 22.8 - 20.7, 22.6 - 20.5 and 22.7 - 20.3, Micotal, 22.8 - 20.4, 22.6 - 20.2, 22.5 - 20.0 and 22.6 - 20.0 and lately Caple 2, $21.4-20.8,21.2-20.3,21.0-20.1$ and $21.2-20.0$., respectively.

Average fruit length as shown in table (5), revealed that all bioinsecticides increased the cucumber fruits length compared with the untreated control. Among the tested bio-insecticides, the mixture of Micotal and Biosect significantly increased the fruit length, 13.8, 14.8, 12.8 and $17.8, \mathrm{~cm}$. while in the untreated it was $12.8,13.0$, 11.5 and 15.7 for the varieties Madena, Amera, Dama and Maram, respectively.

Regarding the effect of the tested bio-insecticides on the fruit weight, all bioinsecticides slightly increased fruit weight compared with untreated control. The mixture revealed the highest increase, followed by Micotal, Biosect and Cable 2 (Table $5)$.

Slight increase was obtained in fruit diameter after treatment of all bioinsecticides. This increase proved significant in the variety Dama, ranged, $10.0-11.2$, $\mathrm{cm}$., and in Maram, $11.6-13.2 \mathrm{~cm}$., The treatment of the mixture was superior, followed by Micotal, Biosect and Caple 2.

In conclusion, application of bio-insecticides had an additive effect on the binary induced an increase in cucumber yield. The obtained results showed the possibility to incorporatethe approach into an integrated pest management strategy for the control of B. tabaci (Cuthbertson et. al., 2005). 


\section{REFFERENCES}

1. Abd-Rabou, S. Abd - Rabou Simmons, A. M. 2010. Survey of reproductive host plants of Bemisia tabaci (Hemiptera: Aleyrodidae) in Egypt, including new host records. Ent. News. 121: 5, 456-465.

2. Cuthbertson, A. G. S. and K. F. A. Walters. 2005. Pathogenicity of the entomopathogenic fungus, Lecanicillium muscarium, against the sweet potato whitefly Bemisia tabaci, under laboratory and glasshouse conditions. Mycopath. 160: 4, 315-319.

3. Dattatray S. and B. Uttamrao. 2009. Integration of bioagents and synthetic insecticide in the management of whitefly and its effect on yield in soybean. Karnataka. J. of Agric. Scie. 22: 3, 631-632.

4. Fargalla, F. H., A. M. Taha and M. A. Fahim. 2011. Epidemiology of tomato yellow leaf curl virus in relation to intercropping and insecticidal spray effects on the Bemisia tabaci under field conditions. Acta Hort. 914, 331-336.

5. Fontes, F., H. M. von C. A. Colombo and A. L. Lourencao. 2012. Structure of genetic diversity of Bemisia tabaci(Genn.) (Hemiptera: Aleyrodidae) populations in Brazilian crops and locations. Scientia Agricola. 2012. 69: 1, 47-53.

6. Henderson, C. F. and Telton. 1955. Tests with acaricides against the brown wheat mite. J. Econ. Entomol., 38: 157 - 161.

7. Olleka, A., N. Mandour and Ren ShunXiang. 2009. Effect of host plant on susceptibility of whitefly Bemisia tabaci (Homoptera: Aleyrodidae) to the entomopathogenic fungus Beauveria bassiana (Ascomycota: Hypocreales). Bioco. Scie. and Tech. 2009. 19: 7/8, 717-727.

8. Rao, G. P., P. L. Kumar and R. J. Holguin-Pena. 2008. Cucurbit yellow stunting disorder virus. (Plant Path. Series - 3) Characterization, diagnosis \& management of plant viruses. Volume 3: vegetable and pulse crops. 279-297.

9. Scorsetti, A. C., R. A. Humber, C. Gregorio, de and C. C. Lopez Lastra. 2008. New records of entomopathogenic fungi infecting Bemisia tabaci and Trialeurodes vaporariorum, pests of horticultural crops, in Argentina. BioCont. 53: 5, 787-796.

10. SAS Institute. 1988. SAS/STAT users Guide, Ver. 6.03. SAS Institute Inc., Cary, North Carolina. 


\section{تقييم فاعلية بعض المبيدات الحيوية علي الذبابة البيضاء ومكونات المحصول في الخيار

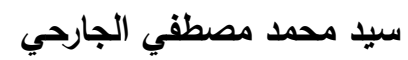 \\ معرة بحوث وقاية النباتات - مركز البحوث الزراعية - الدقي - الجيزة - مصر}

يهـدف هذا البحث لدراسـة النشـاط الحيوي لمتبقيات المستحضـرات التجاريـة الحيويـة وهي

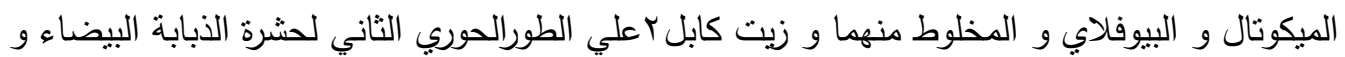

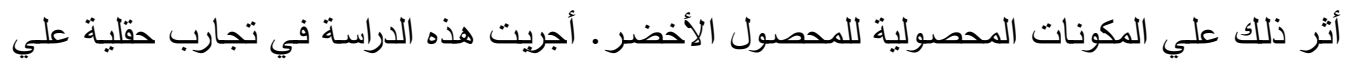

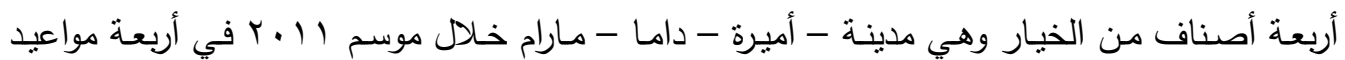
مختلفة للزراعة بمحافظة الفيوم .

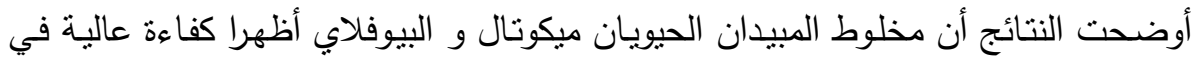
مكافحة الذبابة البيضاء مما أدي إلي زيادة المحصول كما ونوعا، وتلاه البيوفلاي ثم الميكوتال وأخيرا

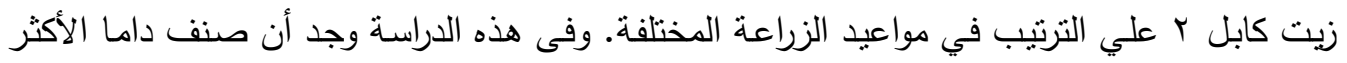

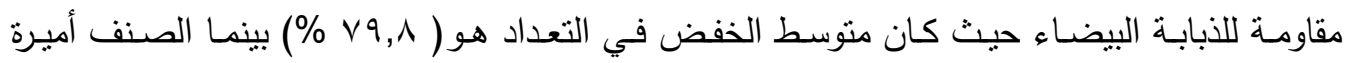

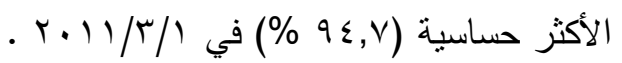

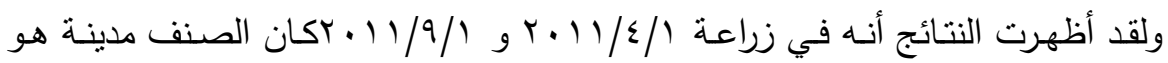
الأكثر مقاومـة حيث كان متوسط الخفض في التعداد ( •, 19\%) بينما الصنف مـارام و أميرة الأكثر

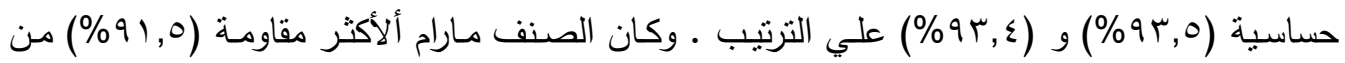

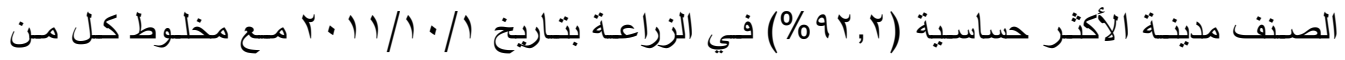
الميكوتال و البيوفلاي. كما وجد أن أفضل مواعيد الزراعة هي أول شهر مارس ثم بداية شهر سبتمبر الزبر

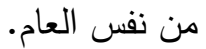

